\title{
An assessment of the multifactorial profile of steroid-metabolizing enzymes and steroid receptors in the eutopic endometrium during moderate to severe ovarian endometriosis
}

\author{
G. Anupa ${ }^{1,2}$, Jai Bhagwan Sharma², Kallol K. Roy², Jayasree Sengupta ${ }^{1}$ and Debabrata Ghosh ${ }^{1 *}$ (D)
}

\begin{abstract}
Background: Previous studies of expression profiles of major endometrial effectors of steroid physiology in endometriosis have yielded markedly conflicting conclusions, presumably because the relative effects of type of endometriosis, fertility history and menstrual cycle phases on the measured variables were not considered. In the present study, endometrial mRNA and protein levels of several effectors of steroid biosynthesis and action in patients with stage III-IV ovarian endometriosis (OE) with known fertility and menstrual cycle histories were compared with the levels in control endometrium to test this concept.

Methods: Endometrial samples were collected from patients without endometriosis $(n=32)$ or OE stages III-IV $(n=52)$ with known fertility and cycle histories. QRT-PCR and immunoblotting experiments were performed to measure levels of NR5A1, STAR, CYP19A1, HSD17Bs, ESRs and PGR transcripts and proteins, respectively. Tissue concentrations of steroids (P4, T, E1 and E2) were measured using ELISAs.

Results: The levels of expression of aromatase and ER $\beta$ were lower $(P<0.0001)$ and $17 \beta-H S D 1(P<0.0001)$ and PRA $(P<0.01)$ were higher in OE endometrium. Lower aromatase levels and higher 17B-HSD1 levels were detected in fertile (aromatase: $P<0.05$; 17B-HSD1: $P<0.0001$ ) and infertile (aromatase: $P<0.0001 ; 17 \beta-H S D 1: P<0.0001$ ) OE endometrium than in the matched control tissues. Both proliferative (PP) and secretory (SP) phase OE samples expressed aromatase $(P<0.0001)$ and ERß (PP: $P<0.001$; SP: $P<0.01)$ at lower levels and 173-HSD1 $(P<0.0001)$ and PRA (PP: $P<0.01$; SP: $P<$ $0.0001)$ at higher levels than matched controls. Higher 17B-HSD1 $(P<0.01)$ and E2 $(P<0.05)$ levels and a lower $(P<0.01)$ PRB/PRA ratio was observed in infertile secretory phase OE endometrium than in control.

Conclusions: We report that dysregulated expression of 17/-HSD1 and PGR resulting in hyperestrogenism and progesterone resistance during the secretory phase of the menstrual cycle, rather than an anomaly in aromatase expression, was the hallmark of eutopic endometrium from infertile OE patients. Furthermore, the results provide proof of concept that the fertility and menstrual cycle histories exerted relatively different effects on steroid physiology in the endometrium from OE patients compared with the control subjects.
\end{abstract}

Keywords: Aromatase, Endometriosis, Endometrium, Infertility, Menstrual cycle, Steroid receptors

\footnotetext{
* Correspondence: debabrata.ghosh1@gmail.com

'Department of Physiology, All India Institute of Medical Sciences, New Delhi,

India

Full list of author information is available at the end of the article
}

(c) The Author(s). 2019 Open Access This article is distributed under the terms of the Creative Commons Attribution 4.0 International License (http://creativecommons.org/licenses/by/4.0/) which permits unrestricted use, distribution, and reproduction in any medium, provided you give appropriate credit to the original author(s) and the source, provide a link to the Creative Commons license, and indicate if changes were made. The Creative Commons Public Domain Dedication waiver (http://creativecommons.org/publicdomain/zero/1.0/) applies to the data made available in this article, unless otherwise stated. 


\section{Introduction}

Endometriosis is characterized by the presence of endometrial cells at ectopic loci and is often associated with chronic pelvic pain, dysmenorrhea, dyspareunia, dysuria, dyschesia and subfertility. It is a multifactorial disease that is widely prevalent among women of reproductive age. Retrograde menstruation followed by the adherence of stromal fibroblasts in the menstrual effluent is believed to be the pathophysiological mechanism underlying the onset of this disease [1]. Although retrograde menstruation occurs in $90 \%$ of women, only 1 in 10 women develop endometriosis, suggesting that an intrinsic anomaly in the eutopic endometrium of women with endometriosis may be one causal factor [2-5]. Endometriosis is generally postulated to be associated with steroid physiology in the target tissues [4, 5]. Increased activity of estrogen with or without progesterone resistance are suggested to be associated with this disease state [6]. The actions of estradiol-17 $\beta$ via its receptor (ER) are known to increase the proliferation of endometrial epithelial, stromal and endothelial cells in the eutopic endometrium of patients with endometriosis [7-9]. Additionally, a loss of progesterone receptivity and signaling vis-à-vis the suppression of progesterone receptor (PGR) activity in the endometrium and in ectopic lesions has been reported to be associated with endometriosis $[10,11]$. Moreover, differential local metabolism of the major steroids, e.g., progesterone (P4), testosterone (T), estrone (E1) and estradiol-17 $\beta$ (E2), occurs in the eutopic endometrium and ectopic lesions during endometriosis in a menstrual phase-specific manner [12, 13]. In fact, several reports have described markedly conflicting results for the transcript and protein levels of the major steroid-synthesizing enzymes, steroidogenic co-factors, and the receptors for estrogen and progesterone in ovarian endometriosis (see Tables 1 and 2 for details). For example, marked differences in the level of aromatase activity have been observed in the endometrium of women with and without endometriosis. Noble et al. (1997) reported very low basal activity of aromatase in the eutopic endometrium of patients with endometriosis, as detected with a biochemical assay using $3 \mathrm{H}$ androstenedione; however, aromatase activity in cultured endometrial stromal cells isolated from patients with endometriosis was increased by several fold in response to db-cAMP [14]. The expression of the CYP19A1 (aromatase) mRNA was found to be 14.5-fold higher in the mid-secretory phase, eutopic endometrium of infertile patients with mainly severe endometriosis of rectovaginal, peritoneal and ovarian subtypes compared with the

Table 1 Studies on factors regulating steroid synthesis in eutopic endometrium during ovarian endometriosis ${ }^{\mathrm{a}}$

\begin{tabular}{|c|c|c|c|}
\hline Reference [No.] & $\begin{array}{l}\text { Type of endometriosis [sample } \\
\text { type and size] }\end{array}$ & $\begin{array}{l}\text { Major technique(s) } \\
\text { employed }\end{array}$ & Salient observations \\
\hline Noble et al., 1997 [14] & $\begin{array}{l}\text { OE }[C E(n=7), \text { EE }(n=2), \\
\text { EC }(n=4)]\end{array}$ & $\begin{array}{l}\text { Biochemical assay, } \\
\text { qRTPCR }\end{array}$ & $\begin{array}{l}\text { Low basal activity in EE but not reported for CE. Details of } \\
\text { fertility status and phase of cycle was not provided. }\end{array}$ \\
\hline Velasco et al., 2006 [15] & $\begin{array}{l}\mathrm{PE}, \mathrm{OE}[\mathrm{CE}(n=12), \mathrm{EE} \\
(n=54), \mathrm{EC}(n=61)]\end{array}$ & $\mathrm{IHC}$ & $\begin{array}{l}\text { No immunopositive aromatase detected in CE and EE, while } \\
61 \% \text { of EC samples showed aromatase activity. Higher in } \\
\text { secretory phase and in severe stage. No combinatorial analysis } \\
\text { done. No details of fertility history was provided. }\end{array}$ \\
\hline $\begin{array}{l}\text { Aghajanova et al., } \\
2009 \text { [16] }\end{array}$ & $\begin{array}{l}\mathrm{PE}, \mathrm{OE}, \mathrm{DIE}[\mathrm{CE}(n=13 \\
\mathrm{EE}(n=29)]\end{array}$ & qRTPCR, IHC & $\begin{array}{l}\text { Aromatase mRNA expression was 14.5-fold upregulated, with } \\
\text { no change in STAR, CYP11A1,HSD3B1, 2, CYP17A1 and HSD17B1, } \\
2 \text { in EE as compared to CE during mid-secretory phase of cycle. } \\
\text { Fertility status was undefined. }\end{array}$ \\
\hline Colette et al.,2009 [17] & $\begin{array}{l}\text { OE,PE, RV }[C E(n=10) \\
\text { EE_EC }(n=56)]\end{array}$ & $\begin{array}{l}\text { IHC, WB in CE, EE and } \\
\text { EC during both phases } \\
\text { of menstrual cycle }\end{array}$ & $\begin{array}{l}\text { Aromatase mRNA and protein were not detectable cycle. Perls' } \\
\text { stain }^{\text {b }} \text { positive siderophages were immunopositive for aromatase. } \\
\text { Fertility history was not reported. }\end{array}$ \\
\hline $\begin{array}{l}\text { Delvoux et al., } \\
2009[18]\end{array}$ & $\begin{array}{l}\text { OE, DIE, SE [CE }(n=20) \\
\text { EE_EC }(n=14)]\end{array}$ & $\begin{array}{l}\text { Biochemical assay, } \\
\text { HPLC }\end{array}$ & $\begin{array}{l}\text { Aromatase activity was not detected in any tissue.No difference } \\
\text { in reductive-oxidative activities of } 17 \beta-H S D \text { s between CE and EE } \\
\text { was observed. Details of menstrual cycle phase and fertility history } \\
\text { were not reported. }\end{array}$ \\
\hline Noel et al., 2011 [19] & $\begin{array}{l}\text { PE, OE, DIE }[C E(n=16) \\
\text { EE_EC }(n=72)]\end{array}$ & $\begin{array}{l}\text { IHC. No details of stages } \\
\text { of endometriosis, phases } \\
\text { of menstrual cycle }\end{array}$ & $\begin{array}{l}\text { No immunoreactivity of SF-1 was observed in EE. No details of } \\
\text { stages of endometriosis, phases of cycle and fertility history was } \\
\text { provided. }\end{array}$ \\
\hline $\begin{array}{l}\text { Huhtinen et al. } \\
2012[12]\end{array}$ & $\begin{array}{l}\text { PE, OE, DIE } \\
{[C E(n=11), \mathrm{EE}(n=17)} \\
\mathrm{EC}(n=18)]\end{array}$ & qRTPCR & $\begin{array}{l}\text { Generally, very low expression levels for mRNAs of CYP19A1 and } \\
\text { HSD17B1, while high expression levels for HSD17B2, more during } \\
\text { secretory phase, was detected in CE and EE with no difference } \\
\text { between the groups. No details of stages of endometriosis and } \\
\text { fertility history was provided. }\end{array}$ \\
\hline
\end{tabular}

${ }^{a}$ studies which did not (i) mention specifically the types of endometriosis, (ii) include CE as well as EE samples, (iii) include OE samples, were not selected ${ }^{b}$ Perls' Prussian blue stain for ferritin. CE Control endometrium, DIE Deep infiltrating endometriosis, EC Ectopic lesion, EE Eutopic endometrium, EE_EC Autologous eutopic and ectopic tissues, HPLC High performance liquid chromatography, IHC Immunohistochemistry, OE Ovarian endometriosis, PE Peritoneal endometriosis, qRTPCR quantitative reverse transcriptase polymerase chain reaction, RV Rectovaginal endometriosis, SE Scar endometriosis, WB Western blotting 
Table 2 Studies on estrogen receptor (ER) and progesterone receptor (PGR), and their subtypes in eutopic endometrium during ovarian endometriosis $^{a}$

\begin{tabular}{|c|c|c|c|}
\hline Reference[No.] & $\begin{array}{l}\text { Type of endometriosis [sample } \\
\text { type and size] }\end{array}$ & Major technique(s) used & Salient observations with remarks \\
\hline Lessey et al., 1989 [20] & $\begin{array}{l}\text { PE, OE, DIE [CE }(n=25), \\
\mathrm{EE}(n=12), \mathrm{EC}(n=9)]\end{array}$ & $\mathrm{IHC}$ & $\begin{array}{l}\text { No difference was observed in the ER and PGR levels } \\
\text { between CE and EE, as well as, between EE and EC. } \\
\text { Analysis between CE and EE was not done based on } \\
\text { phases of menstrual cycle despite tissue samples were } \\
\text { collected during both cycle phases. Fertility history was } \\
\text { not provided. }\end{array}$ \\
\hline Burney et al., 2007 [10] & $\begin{array}{l}\text { PE, OE [CE }(n=16), \\
\mathrm{EE}(n=21)]\end{array}$ & Microarray qRTPCR & $\begin{array}{l}\text { 2.3-fold downregulation of PGR mRNA was observed in } \\
\text { EE compared to CE. Analysis between CE and EE was not } \\
\text { done based on phases of menstrual cycle despite tissue } \\
\text { samples were collected during both phases of menstrual } \\
\text { cycle. Fertility history was not provided. }\end{array}$ \\
\hline Bukulmez et al., 2008 [21] & $\begin{array}{l}\mathrm{PE}, \mathrm{OE}[\mathrm{CE}(n=8), \\
\mathrm{EE}(n=12), \mathrm{EC}(n=14)]\end{array}$ & qRTPCR, IHC, WB & $\begin{array}{l}\text { Lower ESR1:ESR2 mRNA ratio was observed in CE and EE } \\
\text { than EC along with higher immunopositivity for ERB } \\
\text { in EC. Lower PRA and PRB was observed in EC as compared } \\
\text { to EE and CE. Analysis based on phases of menstrual cycle } \\
\text { was not reported despite tissue samples were collected } \\
\text { during both cycle phases. No information on stages of } \\
\text { endometriosis and fertility history was provided. }\end{array}$ \\
\hline Cavallini et al., 2011 [22] & $\begin{array}{l}\text { OE [CE }(n=10), \\
\text { EE_EC }(n=10)]\end{array}$ & qRTPCR, ELISA, IHC & $\begin{array}{l}\text { Protein expression of ERa was higher in EE than CE and } \\
\text { EC with similar expressions in mRNA profiles. Protein } \\
\text { expression of ERß was lower in EE than EC and CE. Higher } \\
\text { PGR mRNA and immunopositivity was observedin EE than } \\
\text { in EC. No data for stages of endometriosis, phases of menstrual } \\
\text { cycle and fertility history was provided. }\end{array}$ \\
\hline Huhtinen et al., 2012 [12] & $\begin{array}{l}\mathrm{PE}, \mathrm{OE}, \mathrm{DIE}[\mathrm{CE}(n=15) \\
\mathrm{EE}(n=37), \mathrm{EC}(n=41)]\end{array}$ & qRTPCR & $\begin{array}{l}\text { ESR1 mRNA expression was lower in both phases of menstrual } \\
\text { cycle in EC than CE. ESR1 mRNA was found to be lower in } \\
\text { secretory phase as compared to proliferative phase in EE. ESR2 } \\
\text { mRNA was higher in EC (OE and DIE) than CE in both phases. } \\
\text { No data for stages of endometriosis and fertility history was } \\
\text { provided. }\end{array}$ \\
\hline
\end{tabular}

${ }^{a}$ studies which did not (i) mention specifically the types of endometriosis, (ii) include CE as well as EE samples, (iii) include OE samples were not selected. CE Control endometrium, DIE Deep infiltrating endometriosis, EC Ectopic lesion, EE Eutopic endometrium. EE_EC Autologous eutopic and ectopic tissues, IHC Immunohistochemistry, OE Ovarian endometriosis, PE Peritoneal endometriosis, qRTPCR quantitative real time PCR, WB Western blotting

control subjects. Additionally, endometrial stromal fibroblasts isolated from patients with endometriosis responded positively to PKA stimulation and displayed increased aromatase enzyme activity in vitro [16]. Huhtinen et al. (2012) similarly reported a low level of aromatase expression detected by using qRT-PCR in the midsecretory eutopic endometrium of patients with a severe stage of endometriosis [12]. On the other hand, in several studies, aromatase activity was not detected in the eutopic endometria of women with and without endometriosis $[15,17,18]$.

We hypothesized that marked inconsistencies among the observations of endometrial steroid physiology in previous studies might have resulted from the lack of a categorical consideration of the relative effects of fertility and menstrual histories on steroid hormone biosynthesis, metabolism and their receptors in the endometrium of patients with and without ovarian endometriosis (OE). The EPHect guidelines essentially highlight the necessity of developing a consensus on the standardization and harmonization of phenotypic surgical and clinical data and biological sample handling methods in endometriosis research $[23,24]$. In the present study, endometrial samples obtained from thirtytwo (32) control subjects and fifty-two (52) patients with moderate to severe (stages III-IV) OE who had a known fertility history and menstrual cycle phase registered in a tertiary hospital in New Delhi were examined to determine the intra-tissue concentrations of major sex steroid hormones (P4, T, E1 and E2) and the transcript and protein levels of steroid-synthesizing enzymes (CYP19A1/aromatase, HSD17B1/17 $\beta-H S D 1$, and HSD17B2/17 $\beta-H S D 2)$, steroidogenic co-factors (NR5A1/SF-1 and STAR/StAR), and the receptors for estrogen (ESR1/ER $\alpha$ and ESR2/ER $\beta$ ) and progesterone (PGR/PRA and PRB) to test this concept. To our knowledge, this study is the first to explore the relative effects of fertility history and menstrual cycle phases on the levels of effectors of steroid physiology in the eutopic endometrium during moderate and severe OE. A schema of the study design is shown in Fig. 1.

\section{Materials and methods}

\section{Patient selection}

Patients enrolled in the Department of Obstetrics and Gynecology of the All India Institute of Medical 


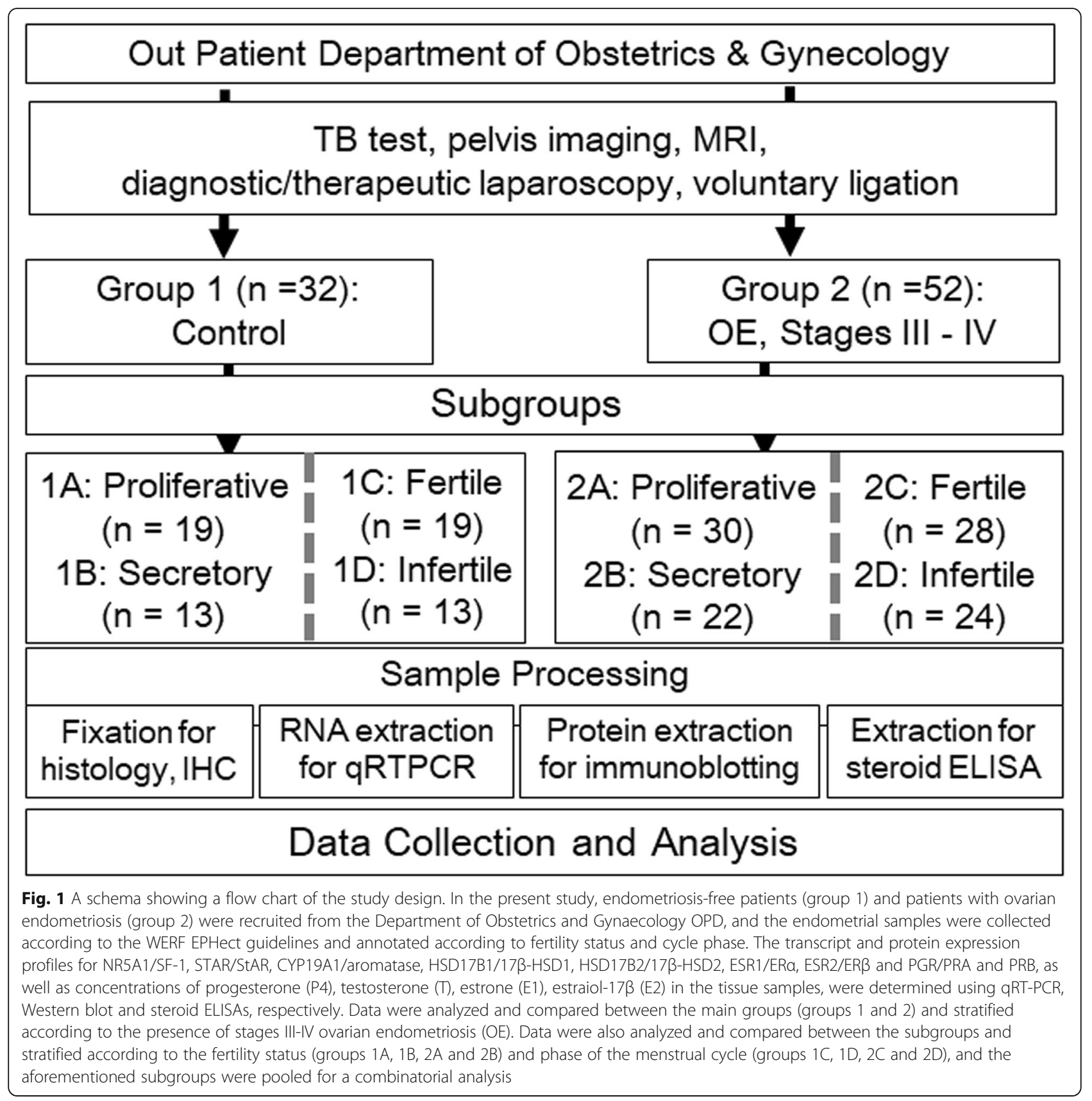

Sciences-Delhi for a surgical intervention for endometriosis, for evaluation at the Infertility Clinic or for family planning voluntarily participated in the study after understanding its purpose and providing written consent, according to the standard protocol. The study was approved by the Institutional Ethics Committee on the Use of Human Subjects (IEC/NP-3/2013; RP-08/04.03.2013) and conducted according to the Declaration of Helsinki Amendment 2013. Fertile patients and patients with primary infertility accompanied by stages III and IV ovarian endometriosis $(\mathrm{OE})$ or no type of endometriosis were enrolled in the study as described elsewhere [25].
Exclusion criteria included the copresence of any other endocrinological disorder, cancer and uterine conditions, such as fibroids, adenomyosis, abnormal bleeding and tuberculosis, since these conditions might affect the results of the study, as described elsewhere [26, 27]. Only those patients who had not taken drugs such as contraceptives, GnRH analogues, aromatase inhibitors, danazol, dienogest or anti-tuberculosis therapy during the last 6 months and who had not undergone any previous laparoscopic surgery were included. Thirty-two (32) disease-free patients formed group 1 and fifty-two (52) patients diagnosed with stages III and IV ovarian 
endometriosis formed group 2. Table 3 provides a detailed description of the characteristics of the patients in the two groups.

\section{Tissue processing}

Proliferative and secretory phase endometrial samples obtained from upper uterine fundus were collected in cold phosphate-buffered saline (PBS, $\mathrm{pH}$ 7.4) using a Karmann cannula, and the samples were immediately washed with PBS, dissected into three parts and transported to the laboratory on ice. One portion was immediately pulverized in liquid nitrogen and stored at $-70{ }^{\circ} \mathrm{C}$ for Western blot experiments and steroid ELISAs, the second portion was incubated with Trizol for RNA extraction, which was stored at $-70{ }^{\circ} \mathrm{C}$ for qRT-PCR, and the third part was fixed with freshly prepared cold $4 \%$ (w/v) paraformaldehyde (Sigma-Aldrich Inc., St. Louis, MO, USA), processed and embedded in paraffin for the histological assessment of the endometrium.

\section{Quantitative RT-PCR (qRT-PCR)}

The steady state expression levels of the transcripts for eight (8) target genes (NR5A1, STAR, CYP19A1, HSD17B1, HSD17B2, ESR1, ESR2 and PGR) were examined in isolated RNA samples with RIN scores of $>8.0$ by using a real time RT-PCR platform (Bio-Rad CFX 96, Bio-Rad Laboratories, Hercules, CA, USA) and a protocol described elsewhere [27, 28]. Briefly, the RNA was reverse transcribed into cDNAs and then amplified using target gene-specific primers according to the manufacturer's protocols (Thermo Fisher Scientific, Waltham, MA, USA). A reaction mixture was prepared in which $4 \mu \mathrm{L}$ of reaction buffer, $1 \mu \mathrm{L}$ of RiboLock RNase inhibitor $(20 \mathrm{U} / \mu \mathrm{L}), 2 \mu \mathrm{L}$ of $10 \mathrm{mM}$ dNTP Mix and $1 \mu \mathrm{L}$ of Revert Aid M-MuLV RT $(200 \mathrm{U} / \mu \mathrm{L})$ were added to the template $(2 \mu \mathrm{g})$ and primer mix $(1 \mu \mathrm{L}$ forward and reverse primer) and heated to $42^{\circ} \mathrm{C}$ for $60 \mathrm{~min}$ for amplification in a thermal cycler. The mixture was heated to
$70{ }^{\circ} \mathrm{C}$ for $5 \mathrm{~min}$ to terminate the reaction and then cooled to $4{ }^{\circ} \mathrm{C}$. The negative control was prepared with all reactants except the reverse transcriptase enzyme. A standard RNA for GAPDH provided with the kit was used at different concentrations to plot the standard curve used to determine the absolute levels of the transcripts of target genes [29]. The copy number was calculated from the expression levels using a standard formula (https://eu.idtdna.com/pages/education). Genespecific forward and reverse primers were designed using the Beacon Designer v12.1 (Premier Biosoft, Palo Alto, CA, USA). The primers sequences are listed in Additional file 1: Table S1.

\section{Immunoblotting}

Western immunoblotting (WB) experiments were performed for nine (9) target proteins (SF-1, StAR, aromatase, $17 \beta-H S D 1,17 \beta-H S D 2, E R \alpha, E R \beta$, PRA and PRB) to measure the relative levels of target proteins using standardized methods [28]. Briefly, the protein concentrations of each lysate were determined by using the Bradford assay, and $25 \mu \mathrm{g}$ of proteins from each sample lysate and prestained molecular weight markers were separated by SDS-PAGE. WB was subsequently performed after proteins were transferred to nitrocellulose membranes using chemicals obtained from Bio-Rad (Hercules, CA, USA). The final visualization was achieved using Abcam Immunoperoxidase kits (Abcam, Cambridge, UK). The respective primary and secondary antibody controls were simultaneously incubated with the membranes to examine antibody specificity. The molecular weights were identified and semiquantitative analyses of the WB bands were performed using densitometry equipment (Pharos FX Molecular Imager) and the optimized densitometry analysis software (QuantityOne) from Bio-Rad (Hercules, CA, USA). For PRA and PRB, the intensities of respective bands were determined from the same runs, as described in a previous study [30]. The optical densities were measured from the log of inverse of

Table 3 Patient details and sample distribution for each experiment

\begin{tabular}{|c|c|c|c|c|c|c|c|c|}
\hline \multirow[t]{2}{*}{ Group [N] } & \multirow[t]{2}{*}{$\begin{array}{l}\text { Subgroup } \\
\text { (n) }\end{array}$} & \multirow[t]{2}{*}{ Description } & \multirow[t]{2}{*}{$\begin{array}{l}\text { Age } \\
\text { (Mean } \pm \text { SD) }\end{array}$} & \multirow[t]{2}{*}{$\begin{array}{l}\text { BMl } \\
(\text { Mean } \pm \text { SD) }\end{array}$} & \multirow[t]{2}{*}{$\begin{array}{l}\text { Cycle day }^{\mathrm{a}} \\
\text { (Mean } \pm \mathrm{SD})\end{array}$} & \multicolumn{3}{|c|}{$\begin{array}{l}\text { Number of samples used in each } \\
\text { experiment }\end{array}$} \\
\hline & & & & & & qRTPCR & WB & ELISA \\
\hline \multirow[t]{4}{*}{ Control (C) [28] } & FPC (13) & Fertile Proliferative Control & $25.3 \pm 1.2$ & $20.1 \pm 1.1$ & $8.2 \pm 1.2$ & 10 & 4 & 4 \\
\hline & IFPC (6) & Infertile ${ }^{\mathrm{b}}$ Proliferative Control & $26.8 \pm 2.1$ & $19.8 \pm 1.2$ & $10.5 \pm 0.9$ & 4 & 4 & 4 \\
\hline & FSC (6) & Fertile Secretory Control & $32.4 \pm 1.7$ & $22.2 \pm 1.3$ & $24 \pm 1.3$ & 4 & 4 & 4 \\
\hline & IFSC (7) & Infertile ${ }^{b}$ Secretory Control & $32.5 \pm 2.7$ & $22.4 \pm 0.8$ & $22 \pm 1.8$ & 4 & 4 & 4 \\
\hline Ovarian & FPU (17) & Fertile Proliferative Eutopic & $31.9 \pm 1.3$ & $20.3 \pm 0.9$ & $9 \pm 0.8$ & 11 & 7 & 4 \\
\hline endometriosis & IFPU (13) & Infertile ${ }^{b}$ Proliferative Eutopic & $27.2 \pm 1.7$ & $22.1 \pm 1.3$ & $11 \pm 1.3$ & 7 & 4 & 4 \\
\hline \multirow[t]{2}{*}{ (OE) [29] } & FSU (11) & Fertile Secretory Eutopic & $34.4 \pm 1.8$ & $22.6 \pm 1.7$ & $22 \pm 1.6$ & 6 & 7 & 4 \\
\hline & IFSU (11) & Infertile ${ }^{b}$ Secretory Eutopic & $19.6 \pm 2.3$ & $21.8 \pm 1.1$ & $23 \pm 1.9$ & 9 & 5 & 4 \\
\hline
\end{tabular}

${ }^{a}$ cycle day of tissue collection

${ }^{b}$ primary infertility cases only. BMI Body mass index, ELISA Steroid ELISA, qRTPCR quantitative RTPCR, WB Western blotting 
transmittance for each target antigen, and the integrated optical densities were normalized to the total protein concentration determined by using the Bradford assay [28, 31]. Additional file 2: Table S2 provides a detailed description of the primary and secondary antibodies used for WB experiments.

\section{Steroid immunoassay}

The concentrations of progesterone (P4), testosterone $(\mathrm{T})$, estradiol-17 $\beta$ (E2) and estrone (E1) were measured in tissue lysates using commercially available ELISA kits obtained from Xema-Medica Co., Ltd. (Moscow, Russia) and Diametra Laboratories (Spello, Italy). For steroid ELISAs, the tissue lysates were prepared in Tris-EDTA buffer according to the manufacturer's protocols. Briefly, tissue homogenates with an estimated protein concentration of $25 \mu \mathrm{g} / \mathrm{ml}$ were loaded in precoated wells of ELISA plates. The wells were then incubated with a conjugated antibody, washed to remove unbound and nonspecifically bound antibody, and then detected using TMB substratebased detection methods. Tissue steroid concentrations are reported as $\mathrm{pmol} / \mathrm{mg}$ of the total protein concentration measured by using the Bradford assay. Additional file 3: Table S3 provides the sensitivity, specificity, intra- and inter-assay coefficients of variances and percent recovery efficiency for each steroid estimated.

\section{Data analysis}

Datasets for downstream analyses were categorized into the main groups (groups 1 and 2) according to the presence of $\mathrm{OE}$, into subgroups according to the fertility (groups 1A, 1B, 2A and 2B), and menstrual (groups 1C, $1 \mathrm{D}, 2 \mathrm{C}$ and $2 \mathrm{D}$ ) histories, and by pooling the abovementioned subgroups for a combinatorial analysis, as explained in the study design (Fig. 1) and group distributions (Table 3). The Kruskal-Wallis test followed by the Mann-Whitney U-test with the Bonferroni correction were used to calculate the statistical significance of the data with a non-Gaussian distribution obtained from the different experiments. Statistical analyses were performed using SPSS v 16.0 software (IBM Analytics, NY, US). In statistical inferences, $P<0.05$ was considered significant.

\section{Results}

\section{General characteristics}

In the next sections, we report the results of the analyses of data used to investigate the effect of $\mathrm{OE}$ on the transcript and protein levels of steroid-synthesizing enzymes (CYP19A1/aromatase, HSD17B1/17 $\beta$-HSD1, and HSD17B2/17 $\beta$-HSD2), steroidogenic co-factors (NR5A1/ SF-1 and STAR/StAR), and the receptors for progesterone (PGR/PRA and PRB) and estrogen (ESR1/ER $\alpha$ and ESR2/ER $\beta$ ) and the intra-tissue concentrations of steroid hormones (P4, T, E1 and E2) in eutopic endometrial samples obtained from eighty-four (84) North Indian patients without and with endometriosis belonging to groups $1(n=32)$ and $2(n=52)$, respectively. We also examined the effects of the fertility status and the phases of menstrual cycle on the parameters examined. As shown in Table 3, the overall profiles of the patients were very similar, with no significant differences in the mean age, BMI and cycle days when the tissue was collected.

\section{Effect of endometriosis}

Figure 2 reports the levels of various transcripts and proteins examined in this study. The steady state levels of the NR5A1 $(P<0.01)$, STAR $(P<0.01)$, CYP19A1 $(P<0.05)$ and ESR2 $(P<0.01)$ transcripts were higher in samples from group 1 (control) than in samples from group 2 (OE). Among the factors showing higher transcript expression in group 1, significantly higher levels of the NR5A1 (i.e., SF-1) $(P<0.01)$, CYP19A1 (i.e., aromatase) $(P<0.0001)$ and ESR2 (i.e., ER $\beta ; P<0.0001)$ proteins were observed compared with group 2. Although the levels of the HSD17B1 and 2 transcripts and the $17 \beta-H S D 2$ protein were not different between the groups, the 17 $\beta$-HSD1 protein was expressed at lower levels $(P<0.0001)$ in the control (group 1) endometrium than in the eutopic endometrium from the OE group. Higher $(P<0.05)$ levels of the PGR and $(P<0.0001)$ PRA transcripts and lower $(P<$ $0.01)$ levels of the PRB transcript were detected in group 2 (OE) than in group 1 (control). However, the steady state levels of the ESR1 and ER $\alpha$ transcripts and proteins did not show any differences between the two groups.

No significant differences in the steady state tissue concentrations of P4 [group 1: 263.9 (134.6-380.0) vs group 2: 111.9 (56.5-415.9); $P=0.87$ ], T [group 1: 110.9 (46.7-162.0) vs group 2: $41.7(16.5-166.0) ; p=0.76]$, E1 [group 1: 22.1 (11.5-30.8) vs group 2: 8.0 (3.4-27.6); $P=$ $0.10)$ ], and E2 [group 1: 75.8 (23.4-157.9) vs group 2: $50.2(10.9-118.0) ; p=0.76]$ were observed between the two groups.

\section{Effect of the fertility status}

Figure 3 shows the steady state transcript and protein levels for all the factors examined based on a supervised classification of the data in terms of the fertility status of the patients. Additional file 8: Figure S1 provides representative images of immunoblots from the different subgroups stratified by fertility status.

Intra-group comparisons between samples obtained from fertile and infertile patients were performed. A comparison of the levels of the target transcripts between samples obtained from control fertile (group 1A) and control infertile (group 1B) patients revealed higher $(P<0.05)$ CYP19A1 expression in the control fertile patients than in 


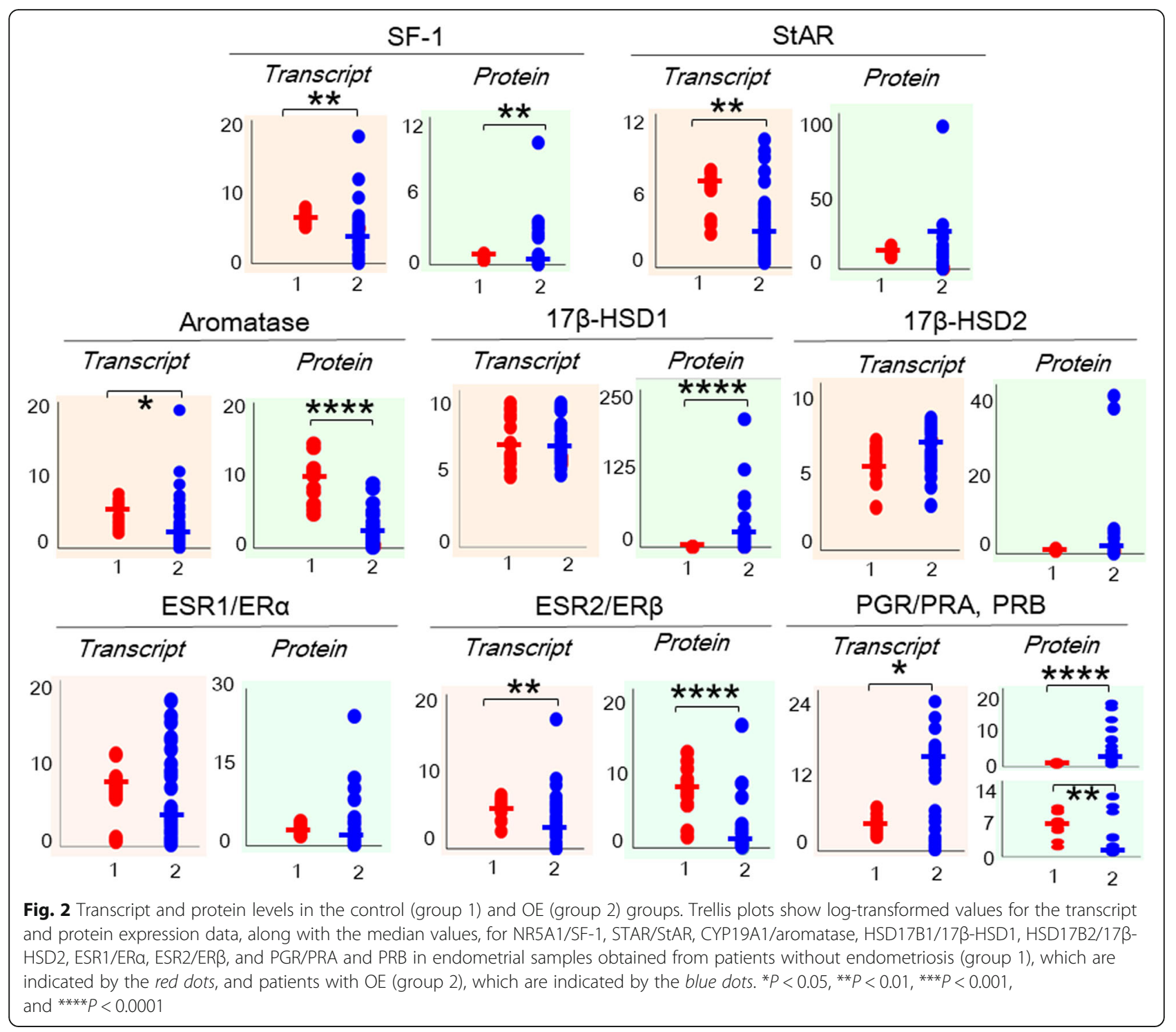

control infertile patients. However, no differences were observed in the protein levels of the other factors examined (SF-1, StAR, aromatase, 17 $\beta$-HSDs, ER $\alpha$, ER $\beta$, PRA and $\mathrm{PRB}$ ). In the comparison between eutopic fertile (group 2A) and eutopic infertile (group 2B) patients, markedly higher $(P<0.0001)$ levels of the STAR, CYP19A1, ESR2 and PGR transcripts and higher $(P<$ $0.01)$ levels of the PRA protein were observed in fertile patients (group 2A) than in infertile patients (group 2B).

Inter-group comparisons between samples obtained from fertile and infertile patients were also performed. The fertile patients in group 1 (group 1A) presented higher $(P<0.05)$ levels of the NR5A1 and StAR transcripts than the eutopic fertile group (group 2A). Higher levels of the aromatase protein $(P<0.05)$ and lower levels of the $17 \beta-$ HSD1 and PRA proteins $(P<0.0001)$ were detected in the control fertile patients (group 1A) than in eutopic fertile patients (group 2A). When samples from the control infertile group (group 1B) were compared with samples from the OE infertile group (group 2B), higher levels of the NR5A1 $(P<0.0001)$, STAR $(P<0.0001)$, CYP19A $(P<0.01)$, ESR1 $(P<0.05)$ and ESR2 $(P<0.001)$ transcripts were detected in group $1 \mathrm{~B}$ than in group $2 \mathrm{~B}$. Higher levels of the StAR $(P<$ $0.05)$, aromatase $(P<0.0001)$ and ER $\beta(P<0.01)$ proteins were detected in the control infertile group (group 1B) than in the eutopic infertile group (group 2B). Lower levels of the $17 \beta-$ HSD1 protein were observed $(P<$ 0.00001 ) in group $1 \mathrm{~B}$ than in group $2 \mathrm{~B}$. No changes were observed in the expression of HSD17B2 and 17 $\beta$-HSD2 in the inter-group comparisons based on the fertility status.

A comparison of the steady state tissue concentrations of steroids revealed lower $(P<0.05)$ levels of testosterone 


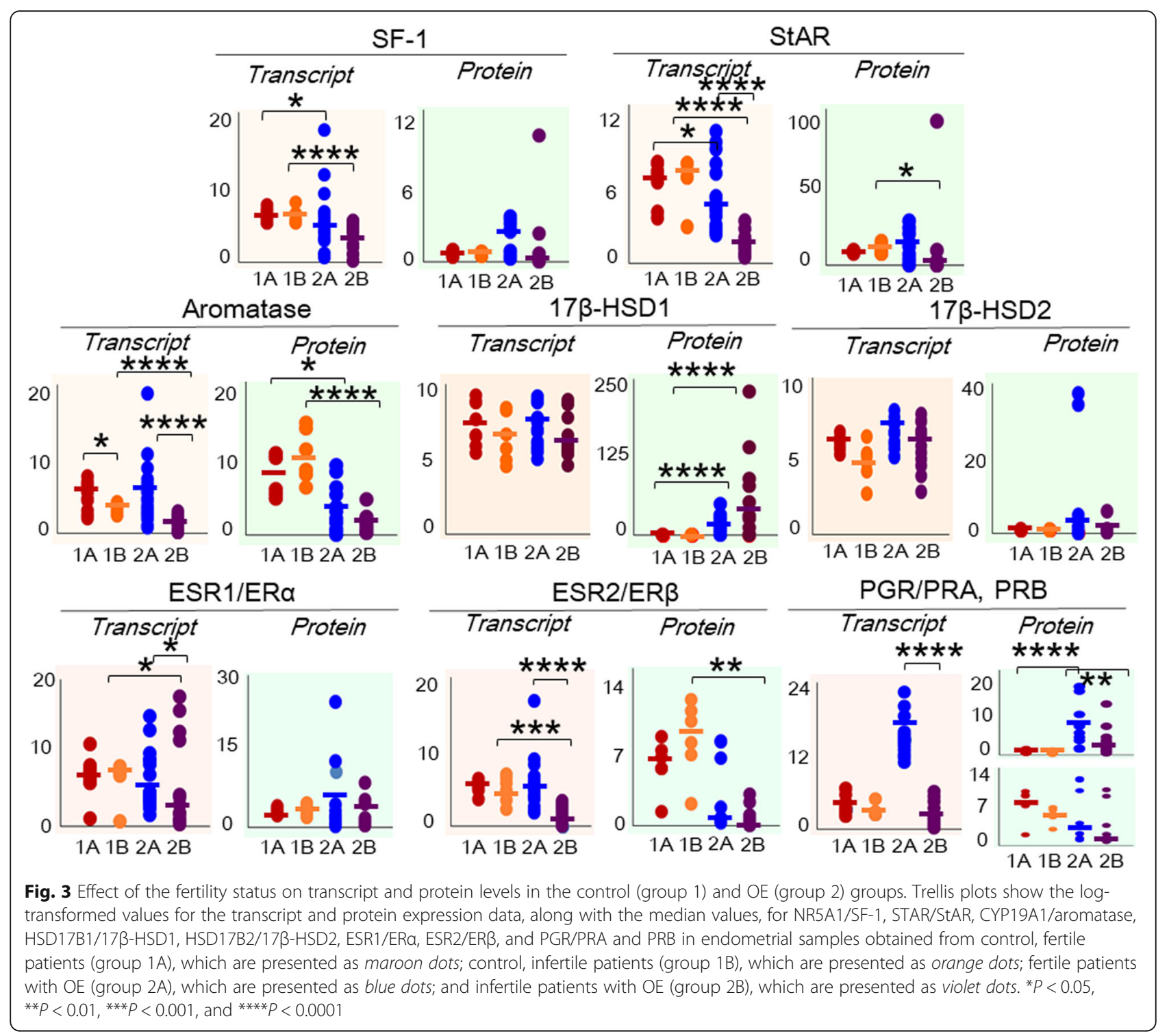

(T) in the control fertile group (group 1A) than in the eutopic fertile group (group 2A), and higher $(P<0.05)$ levels of estrone (E1) were found in samples from the control infertile group (group 1B) than in the eutopic infertile group (group 2B). However, no significant difference was observed in the tissue concentrations of the other steroids studied among samples obtained from fertile and infertile patients with and without endometriosis.

In summary, similar trends of levels of the STAR/ StAR, CYP19A1/aromatase, and HSD17B1/17ß-HSD1 transcripts and proteins were observed in fertile and infertile patients from both groups. However, ESR1/ER $\alpha$, ESR2/ER $\beta$ and PGR/PGA showed marked differences in fertile and infertile patients from the control and $\mathrm{OE}$ groups. Among the steroids examined, a lower tissue concentration of $\mathrm{T}$ was observed in the control fertile group (group 1A) than in the $\mathrm{OE}$ fertile group (group
2A), while a higher E1 concentration was detected in the control infertile group (group 1B) than in the OE infertile group (group 2B).

\section{Effect of phases of the menstrual cycle}

Figure 4 shows the steady state transcript and protein levels of all the factors after the supervised classification of the data based on the menstrual cycle phase of the patients. Additional file 9: Figure S2 provides representative images of immunoblots from the different subgroups stratified according to the menstrual phase.

Intra-group comparisons between samples obtained during the proliferative and secretory phases were performed. A comparison between proliferative (group 1C) and secretory (group 1D) phases of group 1 (control) revealed higher levels $(P<0.05)$ of the CYP19A1 transcript and lower levels $(P<0.01)$ of the ESR2 transcript, along with 


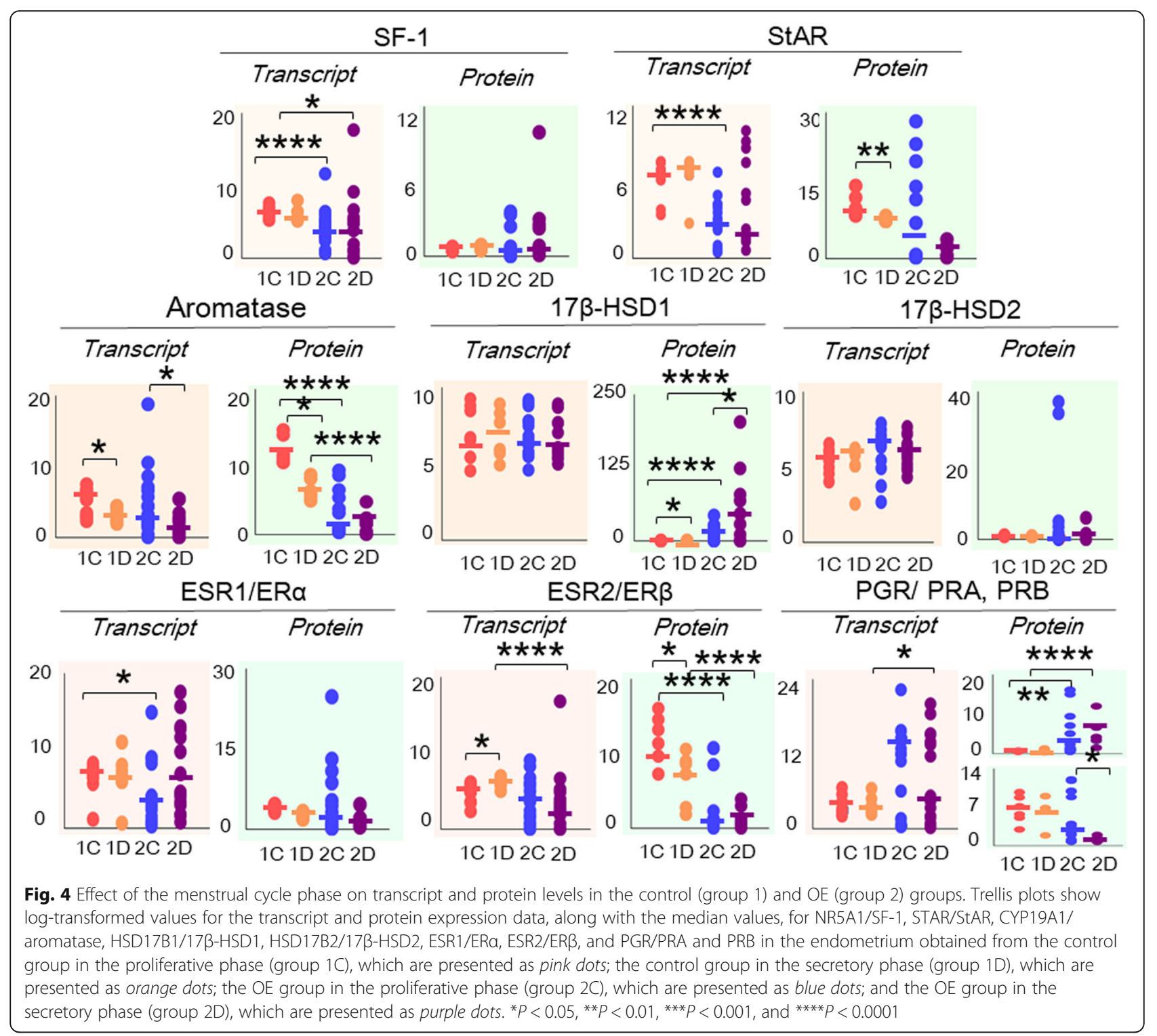

higher levels of the StAR $(P<0.01)$, aromatase $(P<0.01)$, $17 \beta-H S D 1(P<0.05)$ and ESR2 $(P<0.05)$ proteins in the proliferative phase (group $1 C$ ) than in the secretory phase (group 1D). A comparison between the proliferative (group $2 \mathrm{C}$ ) and secretory (group 2D) phases in group $2(\mathrm{OE})$ revealed higher levels $(P<0.05)$ of the CYP19A1 transcript, lower levels $(P<0.05)$ of the $17 \beta$-HSD1 protein, and higher levels $(P<0.01)$ of the PRB protein in the proliferative phase (group 2C) than in the secretory phase in group 2D.

Inter-group comparisons of samples obtained during the proliferative phase and during secretory phase were also performed. As shown in Fig. 4, the comparison between samples obtained in the proliferative phase from group 1 (group $1 C$ ) and group 2 (group 2C) revealed higher expression of the NR5A1 $(P<0.0001)$, STAR $(P<$ $0.0001)$ and ESR1 transcripts $(P<0.05)$, along with higher levels of the aromatase $(P<0.0001)$ and $\operatorname{ER} \beta(P<$ $0.001)$ proteins and lower levels of the 17ß-HSD1 $(P<$ $0.0001)$ and PRA $(P<0.01)$ proteins in group $1 C$ than in group $2 \mathrm{C}$. The secretory phase samples from group 1 (group 1D) displayed higher expression of the NR5A1 $(P<0.05)$ and ESR2 $(P<0.0001)$ transcripts, lower expression of the PGR transcript $(P<0.05)$, higher levels of the aromatase $(P<0.0001), \mathrm{ER} \beta(P<0.01)$ and PRB $(P<$ $0.0001)$ proteins, and lower levels $(P<0.0001)$ of the $17 \beta$-HSD 1 and PRA proteins than to secretory phase samples (group 2D). No change was observed in the expression of HSD17B2 and 17 $\beta$-HSD2 in the inter-group comparisons based on the phase of menstrual cycle.

No significant differences were observed in the tissue concentrations of P4 [group 1C: 167.3 (87.2-380.0), group 1D: 184.9 (84.1-331.9), group 2C: 110.9 (56.5- 
184.0), group 2D: $253.0(101.3-415.0) ; P=0.45)]$, T [group 1C: 63.1 (27.2-161.8), group 1D: 65.9 (46.6142.8), group 2C: 44.4 (16.5-85.4), group 2D: 113.4 (49.9-165.8); $P=0.51$ ], E1 [group 1C: $12.3(9.2-40.3)$, group 1D: 13.5 (8.1-28.8), group 2C: 6.8 (3.4-16.2), group 2D: $18.3(10.2-36.9) ; P=0.12$ ], and $\mathrm{E} 2$ [group 1C: 57.6 (13.2-157.9), group 1D: 25.5 (6.7-69.0), group 2C: 23.1 (10.9-50.2), group 2D: 81.5 (23.1-118.0); $P=0.64]$.

In summary, the expression of the NR5A1 (SF-1), CYP19A1 (aromatase), HSD17B1 (17 $\beta$-HSD1), and ESR2 $(E R \beta)$ transcripts and proteins showed similar trends in the proliferative phase and secretory phase of the menstrual cycle in the control and OE groups. However, marked differences were noted in PGR (PRA and PRB) expression between the two groups. Significant differences in the steady state concentrations of the steroids analyzed were not observed in the intra-group and intergroup comparisons of the proliferative phase and secretory phase samples from the control and $\mathrm{OE}$ groups.

\section{Combinatorial effects of the fertility status and menstrual cycle phase}

Steady state transcript and protein levels of all factors and the intra-tissue concentrations of steroids were also examined after the supervised classification of the data based on the fertility and the menstrual cycle histories of the patients (for details see Additional files 4, 5, 6: Tables S4-S6). The parameters displaying marked changes are summarized in Fig. 5.

A comparative analysis between the fertile proliferative phase subgroup in group 1 (control) and fertile proliferative phase subgroup in group 2 (OE) revealed higher levels $(P<0.05)$ of the aromatase protein in group 1 than in group 2. However, the transcript and protein levels of the other factors studied remained unchanged between these two groups. A comparison between infertile secretory endometrial samples obtained from group 1 (control) and group $2(\mathrm{OE})$ revealed higher $17 \beta$-HSD1 $(P<0.01)$ and PRA $(P<0.05)$ levels along with lower levels of the PRB $(P<0.01)$ protein in samples from group 2. Among patients with $\mathrm{OE}$ (group 2), higher levels of the PGR transcript $(P<0.01)$ and aromatase protein $(P<0.05)$ were detected in the infertile secretory phase endometrium than in infertile proliferative phase endometrium. Steady state measurements of the intratissue concentrations of steroids after the supervised classification of the dataset based on the fertility status and the menstrual cycle phase of the patients did not reveal noticeable changes in the concentrations of the steroid hormones studied, with the exception of E2 levels, which were higher $(P<0.05)$ in the secretory phase endometrial samples from the infertile patients in group $2(\mathrm{OE})$ than in the fertile group.

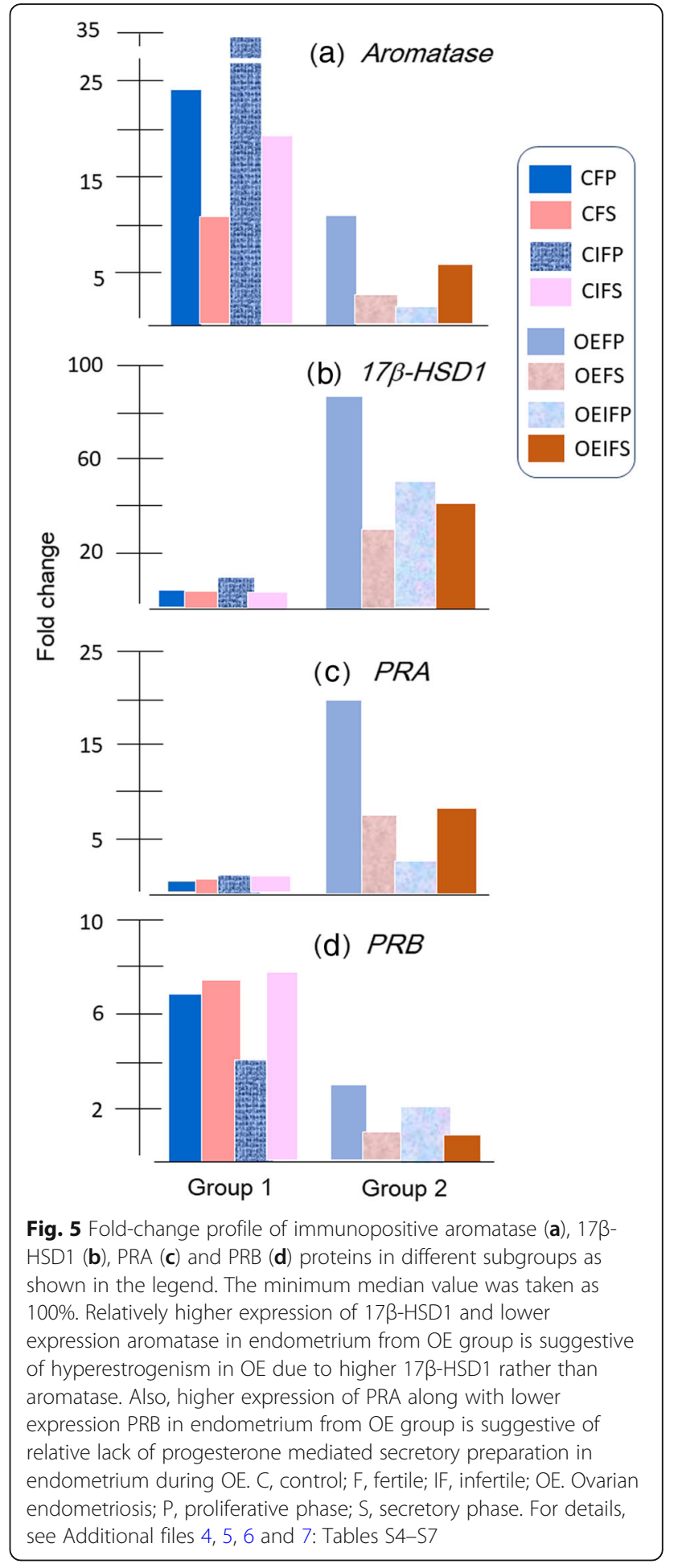

In summary, the eutopic endometrium of infertile patients with $\mathrm{OE}$ exhibited markedly higher $(P<0.01) 17 \beta-$ HSD1 levels, higher $(P<0.05)$ tissue E2 levels, and a lower $(P<0.01)$ PRB:PRA ratio than the control, infertile, secretory phase endometrium during the secretory phase. 


\section{Discussion}

In general, endometriosis is postulated to be associated with hyperestrogenism and progesterone resistance [3, 5, 32-37]. However, as evident from the data presented in Tables 1 and 2, marked incongruences in the reported profiles of transcripts and proteins for major steroid-synthesizing enzymes, steroidogenic co-factors, and the receptors for estrogen and progesterone have been observed in the eutopic endometrium obtained from patients with $\mathrm{OE}$ compared to the disease-free endometrium. We hypothesized that these discrepancies in the findings of previously reported studies might have been attributed to various insufficiencies in the patient grouping and data processing methods, such as an analysis of pooled data from patients with different stages of endometriosis, from samples collected from fertile and infertile patients, and from samples collected during the different phases of menstrual cycle. All these variables are known to affect the final observations of the expression and activities of steroid-metabolizing enzymes, co-factors, and steroid receptors in the endometrium [20, 38-40]. In an attempt to circumvent these limitations, we adopted a method of clear annotation and processing of samples to perform a comparative multiparameter assessment of factors related to estrogen and progesterone turnover and their actions in the eutopic endometrium of patients with $\mathrm{OE}$ and the disease-free endometrium and to study the relative effects of the fertility status and phases of menstrual cycle on these parameters. The present study is the first to substantiate the concept that fertility and menstrual cycle histories differentially affect the endometrial steroid physiology in patients with OE compared to patients with a disease-free endometrium.

In contrast to previous reports describing higher aromatase levels in the eutopic endometria of patients with endometriosis than in the endometrium from diseasefree women, as detected by using RT-PCR and immunochemistry [21, 41], we report significantly lower levels of the CYP19A1/aromatase mRNA and protein in the eutopic endometrium of women with diagnosed $\mathrm{OE}$ in a menstrual phase-specific manner, regardless of their fertility status. This lack of concordance between previous reports and the present study might have several explanations, as discussed below.

(1) The samples analyzed in the many of the previous studies were obtained from patients with different types of endometriosis [12, 17-19, 23] or from patients with extraovarian endometriosis [42, 43]. However, in the present study, samples were obtained from patients with stages III-IV OE and provided highly specific information about aromatase expression in the endometrium of patients with and without OE.
(2) Another potential explanation is the differences in methodologies adopted in previous studies. For example, Kitawaki et al. (1997) employed Southern blot experiments [41], and Bukulmez et al. (2008) assessed the relative expression of untranslated exon IIa to estimate the expression of CYP19A1 transcripts [21]. In this study, we have performed absolute quantification of the copy numbers of the CYP19A1 transcript using the best primers designed by Beacon Designer, which were free of primer-dimer and secondary structures, in qRTPCR.

(3) Ethnic differences might have explained the observed differences. Single nucleotide polymorphisms leading to altered mRNA splicing in the intronic regions of CYP19A1 result in genotypic and allelic variability among populations of women of European and African ancestry [44]. Four different ancestries with wide genetic diversity exist in the Indian subcontinent [45], and differences in single nucleotide polymorphisms in CYP19A1 between women hailing from North India [46] and South India [47] have been observed, which may be associated with differential effects on steroid biochemical phenotypes and altered disease susceptibilities [48-50].

(4) Finally, as described above, most of the previous reports failed to create segregated bins in the data analysis pipeline based on type of endometriosis, severity stage, fertility and menstrual cycle histories, resulting in significant noise in the data mining process. This limitation is now well-acknowledged to frequently yield confusing results. In fact, the WERF EPHect guidelines recommend the adoption of standardized methods for clear annotation, sampling and data mining based on optimized and valid data segregation approaches to avoid the expected high noise in the results [23, 24].

\section{Higher $17 \beta-H S D 1$, but not aromatase, expression is associated with hyperestrogenism in the endometrium during ovarian endometriosis}

Despite marked intra-group variations, the observed higher steady state levels of the NR5A1 and CYP19A1 transcripts and CYP19A1 (aromatase) protein in samples from the control group compared with samples from the OE group, particularly samples from fertile patients, did not corroborate well with a previous report showing that the normal endometrium lacked the ability to synthesize estrogen from androgens due to the absence of StAR and aromatase [12, 14, 17, 34, 37]. However, Tseng et al. (1982) previously reported aromatase activity in the disease-free human endometrium [28]. The expression of $17 \beta-H S D 1$, which catalyzes the $\mathrm{NAD}(\mathrm{P}) \mathrm{H}$-dependent 
reduction of estrone into estradiol [40], was lower in the control endometrium than in OE samples, particularly samples from patients with confirmed fertility. In this connection, the observations of marginally but consistently lower tissue testosterone concentrations in the endometrium from control, fertile patients than in samples obtained from fertile patients with $\mathrm{OE}$, along with a slightly higher level of estrone in samples from the control infertile group than in samples from the eutopic infertile group, might reflect a stochastic mechanism with systems bias in steroid processing in the respective tissues [51]. The physiological importance of marginal changes in the steroid levels in the presence of a robust mover has been addressed in a previous study [52].

As expected, menstrual cycle phase-specific variations in the transcript and protein levels of various enzymes and co-factors, including SF-1, StAR, aromatase and 17ßHSDs, were detected. Notably, relatively higher intratissue concentrations of E2 and 17 $\beta$-HSD1 were observed in infertile patients with endometriosis during the secretory phase. As mentioned above, high 17 $\beta$-HSD1 levels tend to increase the E2 output by about 4-fold in the tissue $[29,40]$. Furthermore, the possibility that the local E2 profile was influenced by aromatase-independent pathways involving the production of E1 from estrone sulfate or dehydroandrostenedione (DHEA) from DHEAS, and the conversion of E1 to E2 and DHEA to androstenediol by $17 \beta-H S D 1$, as observed in hormone responsive primary breast cancer [53] and endometrial cancer [54], must be examined. Notably, higher expression of steroid sulfatase (STS) was observed in stromal cells from the eutopic endometrium of patients with endometriosis [55].

Infertility is prevalent among patients with $\mathrm{OE}$ [56-58]. A plausible hypothesis is that hyperestrogenism in the endometrium during the secretory phase in patients with endometriosis is a likely cause of infertility. Cellular aberrations described in the eutopic endometrium of endometriosis have been observed in the stratum functionalis in the secretory phase, where a persistence of proliferative activity is detected [59-61]. Eutopic stromal cells from patients with $\mathrm{OE}$ show a reduced capacity for decidualization that affects their capacity for proliferation and survival in the ectopic environment [16, 62]. Elevated E2 levels in the eutopic tissue from patients with $\mathrm{OE}$ may play a role in disease progression by upregulating the tissue expression of $ß$-catenin [63], which regulates cell adhesion and migration and functions as a transcription factor regulating endometrial differentiation via the Wnt signaling pathway [64].

Based on the results obtained in the present study, we concluded that eutopic endometrium of patients with OE displayed hyperestrogenism primarily due to dysregulated 17ß-HSD1, particularly in the secretory phase of the menstrual cycle, which may be a cause of the higher rate of implantation failure in this group [3, 4]. Furthermore, Delvoux et al. (2014) revealed that $17 \beta$-HSD1 was a major driving factor for the imbalance in estrogen turnover in endometriotic lesions and suggested that the inhibition of this enzyme might be a potential future treatment strategy for restoring the correct metabolic balance targeted to patients with endometriosis presenting increased local $17 \beta$-HSD1 enzyme activity [65]. The scenario may be different in patients with deep infiltrating endometriosis (DIE), which is characterized by the suppression of $17 \beta$-HSDs 2 and 4 along with increased expression of aromatase and 17 $\beta$-HSD1 [66]. Further studies are warranted to examine these hypotheses.

\section{Dysregulated endometrial progesterone receptor in ovarian endometriosis and infertility}

Higher levels of PRA and lower levels of the ER $\beta$ and PRB proteins, along with a higher level of the PGR transcript, were detected in the OE group than in the disease-free control group. For estrogen, two structurally related ER subtypes, ER $\alpha$ and ER $\beta$ - which are products of two separate genes - signal when complexed with E2. Although the involvement of the ER subtypes $(E R \alpha$ and $E R \beta)$ in the progression of endometriosis is not clear $[67,68]$, the results obtained from the present study of North Indian women concur with the findings reported by Zhang et al. (2018), who also did not observe any change in the levels of the wild type ER $\alpha$ mRNA in a population of fertile Chinese women with and without endometriosis [69].

In the coordinated receptor model for estrogenmediated signaling in human endometrium proposed by Miller and associates (2018), the ERa66 variant is responsible for inducing receptor-mediated signaling cascades to promote cell proliferation along with the activation of a negative regulatory mechanism mediated by ER $\beta$ and Era46 to maintain homeostasis in the presence of hormone transients [70]. In contrast to ER $\alpha$, the low levels of the ESR2 mRNA and ER $\beta$ protein in the eutopic endometrium of women with moderate to severe $\mathrm{OE}$ compared with healthy women observed in the present study are consistent with the low ER $\beta$ levels reported in cells of the eutopic endometrium from patients with endometriosis, which were positively correlated with increased telomerase expression that indicated a persistently greater proliferative phenotype $[71,72]$. While we were unable to detect any marked changes in the ER $\alpha: E R \beta$ ratio in the endometria of women with and without OE, a trend toward higher expression was noted in women with OE. An analysis of the classical paradigm based on the ligand binding-dimerization-transcriptionproliferation of ER subtypes in endometrial cells of normal and OE tissues appears to be warranted to resolve the issue of the marginal shift in the $E R \alpha: E R \beta$ ratio in the $\mathrm{OE}$ endometrium [73]. 
Regarding the progesterone receptor, our observations were consistent with a previous report showing a higher PRA:PRB ratio due to aberrant overexpression of PRA in the eutopic endometrium during OE [74, 75]. Progesterone responsiveness in the endometrium is mediated by the coordinated actions of two receptor isoforms, PRA and $\mathrm{PRB}$, which are transcribed from two different promoters of the single PR gene. One hundred sixty-four amino acids are missing from the amino terminus of PRA compared to PRB [76]. Progesterone action in uterine tissues is qualitatively and quantitatively determined by the relative levels and transcriptional activities of PRA and PRB [77-79]. Human PRB is known to function as an activator of progesterone-responsive genes, while PRA is transcriptionally inactive and additionally functions as a strong transdominant repressor of PRB and ER transcriptional activity [76-79]. In the normal endometrium, the PR isoforms are evenly distributed in the proliferative phase, while PRB is the predominant isoform in nuclear foci in the secretory phase, resulting in a higher PRB:PRA ratio [80]. The results of the present study corroborate the levels of PRA and PRB based on Western immunoblotting of the control, disease-free endometrium, while the higher PRA:PRB ratio observed in samples from patients with moderate to severe OE may be associated with the subsequent repression of PRB activity in the secretory phase of infertile patients. In patients with moderate to severe OE, the environment of the eutopic endometrium appears to undergo a loss of the normal luteal-phase dominance of progesterone with a higher ratio of PRA:PRB, resulting in progesterone resistance and estrogen dominance [81]. In an elegant study, Barragan et al. (2016) observed that human endometrial fibroblasts display progesterone resistance in the endometrial niche in endometriosis [82]. This dysregulated progesterone action notably results in hyperplastic noise in the endometrium [83]. Progesterone action in the secretory phase endometrium is sine qua non for promoting endometrial differentiation and receptivity for embryo implantation in primates [84-86]. Thus, as observed in the present study, dysregulated $P$ receptivity in infertile patients with $\mathrm{OE}$ might be a mechanism underlying the anomalous endometrial gene expression observed in women with repeated implantation failure and infertility [87-89].

\section{Limitations and strengths of the study}

The present study has a major limitation due to the markedly dispersed data points for most of the parameters. This dispersion, combined with supervised factorial suprabinning of data, resulted in a reduction in the number of data points for each subgroup. Nevertheless, our protocol of serially binning the data into groups and subgroups provided the proof of an original concept that differential regulatory homeodynamics of steroids occur in the endometrium, depending on the phases of the menstrual cycle, fertility history and presence of endometriosis.

Furthermore, we did not observe a good correlation between the transcript and corresponding protein levels in the present study, with the exception of the correlations between the levels of the ESR1 and ER $\alpha$ protein and between the levels of the StAR transcript and protein (Additional file 7: Table S7). Good correlations between mRNA and protein levels enable protein levels to be predicted from mRNA levels, which are able to be collected more accurately and easily in a highthroughput manner $[90,91]$. Since the mRNA is eventually translated into protein, a reasonable assumption is that some correlation should exist between the mRNA and protein levels. The steady state levels of various mRNAs represent a profile of the related genomic expression and provides useful values in a broad range of applications, including the diagnosis and classification of disease, but these results are only correlative and not causative [92, 93]. On other hand, the concentration of proteins and their interactions reflect causative pathways in the cell $[91,94]$. Thus, the quantification of both of these molecular populations is not an exercise in redundancy; measurements of mRNA and protein levels are complementary, and both are necessary to obtain a complete understanding of a physiological state, even if an overt correlation does not exist between these two sets of data, as observed in the present study [95]. At least three reasons presumably explain the poor correlations between the mRNA and protein levels, which may not be mutually exclusive [95]. First, many complex and dynamic posttranscriptional mechanisms are involved in the ultimate translation of the mRNA into a protein, and our understanding of these processes is grossly insufficient. Second, proteins generally differ substantially in their half-lives in situ. Third, a significant signal-noise ratio and error exist in both protein and mRNA experiments, which are also not hyperstatic modules. All these biological properties are dynamic and depend on the biochemical nuances of the attractor properties of the homeodynamics of particular physiological and pathophysiological states [96].

Thus, based on our observed results revealing a marked lack of correlation and correspondence in the mRNA and protein levels examined in the endometrium obtained from fertile and infertile patients with or without OE during different phases of cycle, we conjecture that differential regulatory homeodynamics of the steroids occur in the human endometrium, depending on its ecological succession with the phase of menstrual cycle, fertility history and the presence of endometriosis $[86,97]$.

Finally, we report for the first time that there exists lower levels of the CYP19A1/aromatase mRNA and protein in the eutopic endometrium of women with 
diagnosed OE in a menstrual phase-specific manner, regardless of their fertility status. Thus, we conclude that dysregulated $17 \beta-H S D 1$ expression and alterations in the PRA:PRB ratio resulting in hyperestrogenism and progesterone resistance during the secretory phase of the menstrual cycle, rather than an anomaly in aromatase expression, were the hallmarks of the eutopic endometrium of infertile patients with OE. Moreover, our results provide proof of concept for the different effects of the fertility history and menstrual cycle phases on steroid physiology in the endometrium of patients with moderate to severe $\mathrm{OE}$ compared with control subjects.

\section{Supplementary information}

Supplementary information accompanies this paper at https://doi.org/10. 1186/s12958-019-0553-0.

\section{Additional file 1: Table S1. List of primers for $q R T P C R$. \\ Additional file 2: Table S2. List of primary antibodies used in Western immunoblotting.}

Additional file 3: Table S3. Sensitivity, specificity, intra- and inter-assay coefficients of variances (CV) and per cent recovery efficiency of endometrial tissue steroids estimated.

Additional file 4: Table S4. Endometrial transcript and protein expression of factors involved in steroid biosynthesis in patients with and without endometriosis.

Additional file 5: Table S5. Endometrial transcript and protein expression of estrogen and progesterone receptors in patients with and without endometriosis.

Additional file 6: Table S6. Tissue steroid hormone concentration (pmol/mg protein) in endometrium of patients with and without endometriosis.

Additional file 7: Table S7. Correlation between transcripts and protein levels.

Additional file 8: Figure S1. Representative images of Western blots showing the effect of the fertility history on the levels of the SF-1, StAR, aromatase, 17 $\beta-H S D 1,17 \beta-H S D 2, E R a, E R \beta, P R A$ and PRB proteins in endometrial samples from the control, fertile (C,F; group 1A); control, infertile (C,IF; group 1B); OE, fertile (OE,F; group 2A); and OE, infertile (OE,IF; group 2B) groups. Tissue lysates of samples from these groups ( $25 \mu \mathrm{g}$ of proteins, concentrations were determined by using the Bradford assay) were subjected to electrophoretic separation followed by immunoblot analysis. The relative optical densities were measured by performing an integrated image analysis and normalizing the value to the $\mu \mathrm{g}$ of total protein.

Additional file 9: Figure S2. Representative images of Western blots showing the effect of the menstrual cycle phase on the levels of the SF1, StAR, aromatase, 17 $\beta-H S D 1,17 \beta-H S D 2, E R a, E r \beta, P R A$ and PRB proteins in endometrial samples from the control, proliferative (C,P; group 1C); control, secretory (C,S; group 1D); OE, proliferative (OE,P; group 2C); and $\mathrm{OE}$, secretory (OE,S; group 2D) groups. Tissue lysates of samples from these groups ( $25 \mu \mathrm{g}$ of protein, concentrations were determined by using the Bradford assay) were subjected to electrophoretic separation followed by immunoblot analysis. The relative optical densities were measured by performing an integrated image analysis and normalizing the values to the $\mu \mathrm{g}$ of total protein.

\section{Acknowledgements}

The authors express their gratitude to the patients who volunteered to participate after understanding the goal of the proposed study. The authors acknowledge the comments of the reviewers that helped to improve the manuscript.

\section{Authors' contributions}

AG collected the samples, performed the experiments, analyzed the data and wrote the initial draft of the manuscript as a part of her Ph.D. thesis study in AlIMS-Delhi. JBS and KKR collected tissue samples. JS participated in designing the study, data analysis, data interpretation and drafting and revision of the manuscript. DG conceived the study, participated in its design, coordination, data analysis and interpretation and in the drafting of the manuscript and its revision. All authors read and approved the final manuscript.

\section{Funding}

The study was supported by a project grant from the Scientific and Engineering Research Board (SERB), Government of India (EMR/2016/002255 (D-437)

Availability of data and materials

All the data and residual materials are well preserved and hence available with the group.

\section{Ethics approval and consent to participate}

All procedures described in this study were reviewed and approved by the Ethics Committee of All India Institute of Medical Sciences, New Delhi. All procedures were performed in accordance with the guidelines for the use of human subjects listed in the Declaration of Helsinki in 2013 and Ethics Committee of All India Institute of Medical Sciences, New Delhi, reference numbers IEC/NP-33/2013 \& RP-08/04.03.2013.

\section{Consent for publication}

As per Institutional Ethics protocol, all necessary permissions were obtained from all the participants in writing.

\section{Competing interests}

The authors declare that they have no competing interests.

\section{Author details}

${ }^{1}$ Department of Physiology, All India Institute of Medical Sciences, New Delhi, India. ${ }^{2}$ Department of Obstetrics and Gynecology, All India Institute of Medical Sciences, New Delhi, India.

Received: 22 August 2019 Accepted: 4 December 2019

Published online: 26 December 2019

\section{References}

1. Warren LA, Shih A, Renteira SM, Seckin T, Blau B, Simpfendorfer K, et al. Analysis of menstrual effluent: diagnostic potential for endometriosis. Mol Med. 2018;24(1):1

2. Liu H, Lang JH. Is abnormal eutopic endometrium the cause of endometriosis? The role of eutopic endometrium in pathogenesis of endometriosis. Med Sci Monit. 2011;17(4):RA92-9.

3. Brosens I, Brosens JJ, Benagiano G. The eutopic endometrium in endometriosis: are the changes of clinical significance? Reprod BioMed Online. 2012;24(5):496-502.

4. Sengupta J, Anupa G, Bhat MA, Ghosh D. In: Schatten H, editor. Molecular biology of endometriosis. In: Human Reproduction: Updates and New Horizons. Ed: Wiley. Hoboken: Wiley \& Sons, Inc.; 2017. p. 71-116.

5. Bulun SE, Yilmaz BD, Sison C, Miyazaki K, Bernardi L, Liu S, et al. Endometriosis. Endocr Rev. 2019;40(4):1048-79.

6. McKinnon B, Mueller M, Montgomery G. Progesterone resistance in endometriosis: an acquired property? Trends Endocrinol Metab. 2018;29(8): 535-48.

7. Wingfield M, Macpherson A, Healy DL, Rogers PA. Cell proliferation is increased in the endometrium of women with endometriosis. Fertil Steril. 1995;64(2):340-6.

8. Klemmt PA, Carver JG, Koninckx P, McVeigh EJ, Mardon HJ. Endometrial cells from women with endometriosis have increased adhesion and proliferative capacity in response to extracellular matrix components: towards a mechanistic model for endometriosis progression. Hum Reprod. 2007:22(12):3139-47.

9. da Costa e Silva Rde C, Moura KK, Ribeiro Júnior CL, Guillo LA. Estrogen signaling in the proliferative endometrium: implications in endometriosis. Rev Assoc Med Bras. (1992). 2016;62(1):72-7. 
10. Burney RO, Talbi S, Hamilton AE, Vo KC, Nyegaard M, Nezhat CR, et al. Gene expression analysis of endometrium reveals progesterone resistance and candidate susceptibility genes in women with endometriosis. Endocrinology. 2007;148(8):3814-26.

11. Patel BG, Rudnicki M, Yu J, Shu Y, Taylor RN. Progesterone resistance in endometriosis: origins, consequences and interventions. Acta Obstet Gynecol Scand. 2017;96(6):623-32

12. Huhtinen $K$, Desai R, Ståhle M, Salminen A, Handelsman DJ, Perheentupa A, et al. Endometrial and endometriotic concentrations of estrone and estradiol are determined by local metabolism rather than circulating levels. J Clin Endocrinol Metab. 2012;97(11):4228-35.

13. Huhtinen K, Saloniemi-Heinonen T, Keski-Rahkonen P, Desai R, Laajala D, Ståhle $M$, et al. Intra-tissue steroid profiling indicates differential progesterone and testosterone metabolism in the endometrium and endometriosis lesions. J Clin Endocrinol Metab. 2014:99(11):E2188-97.

14. Noble LS, Takayama K, Zeitoun KM, Putman JM, Johns DA, Wood MMH, Agarwal VR, Zhao Y, Carr BR, Bulun SE. Prostaglandin E2 stimulates aromatase expression in endometriosis-derived stromal cells. J Clin Endocrinol Metab. 1997:82(2):600-6.

15. Velasco I, Rueda J, Acién P. Aromatase expression in endometriotic tissues and cell cultures of patients with endometriosis. Mol Hum Reprod. 2006; 12(6):377-81.

16. Aghajanova L, Hamilton A, Kwintkiewicz J, Vo KC, Giudice LC. Steroidogenic enzyme and key decidualization marker dysregulation in endometrial stromal cells from women with versus without endometriosis. Biol Reprod. 2009:80(1):105-14.

17. Colette S, Lousse JC, Defrère S, Curaba M, Heilier JF, Van Langendonckt A, et al. Absence of aromatase protein and mRNA expression in endometriosis. Hum Reprod. 2009;24(9):2133-41.

18. Delvoux B, Groothuis P, D'Hooghe T, Kyama C, Dunselman G, Romano A Increased production of 17 beta-estradiol in endometriosis lesions is the result of impaired metabolism. J Clin Endocrinol Metab. 2009;94(3):876-83.

19. Noël JC, Anaf V, Borghese B, Vaiman D, Fayt I, Chapron C. The steroidogenic factor-1 protein is not expressed in various forms of endometriosis but is strongly present in ovarian cortical or medullary mesenchymatous cells adjacent to endometriotic foci. Fertil Steril. 2011:95(8):2655-7.

20. Lessey BA, Metzger DA, Haney AF, McCarty KS Jr. Immunohistochemical analysis of estrogen and progesterone receptors in endometriosis: comparison with normal endometrium during the menstrual cycle and the effect of medical therapy. Fertil Steril. 1989;51(3):409-15.

21. Bukulmez O, Hardy DB, Carr BR, Auchus RJ, Toloubeydokhti T, Word RA, et al. Androstenedione up-regulation of endometrial aromatase expression via local conversion to estrogen: potential relevance to the pathogenesis of endometriosis. J Clin Endocrinol Metab. 2008;93(9):3471-7.

22. Cavallini A, Resta L, Caringella AM, Dinaro E, Lippolis C, Loverro G. Involvement of estrogen receptor-related receptors in human ovarian endometriosis. Fertil Steril. 2011;96(1):102-6.

23. Fassbender A, Rahmioglu N, Vitonis AF, Viganò P, Giudice LC, D'Hooghe TM, et al. World endometriosis Research Foundation endometriosis Phenome and biobanking harmonisation project: IV. Tissue collection, processing, and storage in endometriosis research. Fertil Steril. 2014;102(5):1244-53.

24. Miller LM, Johnson NP. EPHect - the Endometriosis Phenome (and Biobanking) Harmonisation Project - may be very helpful for clinicians and the women they are treating. F1000Res. 2017;6:14.

25. Negi N, Roy KK, Kumar S, Nair VG, Vanamail P. Clinical outcome analysis and correlation of reproductive outcome with endometriosis fertility index in laparoscopically managed endometriosis patients: a retrospective cohort study. J Hum Reprod Sci. 2019;12(2):98-3.

26. Sharma JB, Karmakar D, Hari S, Singh N, Singh SP, Kumar S, Roy KK. Magnetic resonance imaging findings among women with tubercular tuboovarian masses. Int J Gynaecol Obstet. 2011;113(1):76-80

27. Khan MA, Sengupta J, Mittal S, Ghosh D. Genome-wide expressions in autologous eutopic and ectopic endometrium of fertile women with endometriosis. Reprod Biol Endocrinol. 2012;10:84.

28. Anupa G, Bhat MA, Srivastava AK, Sharma JB, Mehta N, Patil A, et al. Cationic antimicrobial peptide, magainin down-regulates secretion of proinflammatory cytokines by early placental cytotrophoblasts. Reprod Biol Endocrinol. 2015;13(1):121.

29. Bustin SA. Absolute quantification of mRNA using real-time reverse transcription polymerase chain reaction assays. J Mol Endocrinol. 2000;25(2): 169-93.
30. Fabris V, Abascal MF, Giulianelli S, May M, Sequeira GR, Jacobsen B, et al. Isoform specificity of progesterone receptor antibodies. J Pathol Clin Res. 2017;3(4):227-33.

31. Sambrook J, Russell DW. Commonly used techniques in molecular cloning. In: Sambrook J, Russell DW, editors. Molecular Cloning. Eds. Cold Spring Harbor, NY, USA: Cold Spring Harbor Laboratory Press; 2001.

32. Tseng L, Mazella J, Mann WJ, Chumas J. Estrogen synthesis in normal and malignant human endometrium. J Clin Endocrinol Metab. 1982;55(5):1029-31.

33. Moeller G, Adamski J. Multifunctionality of human 17beta-hydroxysteroid dehydrogenases. Mol Cell Endocrinol. 2006;248(1-2):47-55.

34. Attar E, Bulun SE. Aromatase and other steroidogenic genes in endometriosis: translational aspects. Hum Reprod Update. 2006;12(1):49-56.

35. Critchley HO, Saunders PT. Hormone receptor dynamics in a receptive human endometrium. Reprod Sci. 2009;16(2):191-9.

36. Vigano P, Rabellotti E, Pagliardini L, Somigliana E, Candiani M, Vercellini P. Progesterone resistance, aromatase, and inflammation: the important relationships between hormones and inflammation. Curr Obstet Gynecol Rep. 2012;1:146.

37. Qi QM, Guo SW, Liu XS. Estrogen biosynthesis and its regulation in endometriosis. Reprod Dev Med. 2017;1(1):55-61.

38. McGee EA, Strauss JF III. Ovarian hormone synthesis. In: Jameson JL, De Groot LJ, editors. Endocrinology: Adult and Paediatric. Eds. Philadelphia: Elsevier Saunders Publishing: 2016. p. 2192-206.

39. Marshall JC. The menstrual cycle and disorders of ovulation. In: Jameson JL, De Groot L, editors. Endocrinology: Adult and Paediatric. Eds. Philadelphia: Elsevier Saunders Publishing; 2016. p. 2231-41.

40. Penning TM. Hydroxysteroid dehydrogenases and pre-receptor regulation of steroid hormone action. Hum Reprod Update. 2003:9(3):193-205.

41. Kitawaki J, Noguchi T, Amatsu T, Maeda K, Tsukamoto K, Yamamoto T, et al. Expression of aromatase cytochrome $\mathrm{P} 450$ protein and messenger ribonucleic acid in human endometriotic and adenomyotic tissues but not in normal endometrium. Biol Reprod. 1997;57(3):514-9.

42. Noble LS, Simpson ER, Johns A, Bulun SE. Aromatase expression in endometriosis. J Clin Endocrinol Metab. 1996;81(1):174-9.

43. Wolfler MM, Nagele F, Kolbus A, Seidl S, Schnerder B, Huber JC, Tschugguel WT. A predictive model of endometriosis. Hum Reprod. 2005;20(6):1702-8

44. Starlard-Davenport A, Orloff MS, Dhakal I, Penney RB, Kadlubar SA. Genotypic and allelic variability in CYP19A1 among populations of African and European ancestry. PLoS One. 2015;10(2):e0117347.

45. Basu A, Sarkar-Roy N, Majumder PP. Genomic reconstruction of the history of extant populations of India reveals five distinct ancestral components and a complex structure. Proc Natl Acad Sci U S A. 2016:113(6):1594-9.

46. Chattopadhyay S, Siddiqui S, Akhtar MS, Najm MZ, Deo SV, Shukla NK, et al. Genetic polymorphisms of ESR1, ESR2, CYP17A1, and CYP19A1 and the risk of breast cancer: a case control study from North India. Tumour Biol. 2014; 35(5):4517-27

47. Umamaheswaran G, Dkhar SA, Kalaivani S, Anjana R, Revathy M, Jaharamma $M$, et al. Haplotype structures and functional polymorphic variants of the drug target enzyme aromatase (CYP19A1) in south Indian population. Med Oncol. 2013;30(3):665.

48. Olson SH, Bandera EV, Orlow I. Variants in estrogen biosynthesis genes, sex steroid hormone levels, and endometrial cancer: a HuGE review. Am J Epidemiol. 2007;165(3):235-45.

49. Mastana SS. Unity in diversity: an overview of the genomic anthropology of India. Ann Hum Biol. 2014;41(4):287-99.

50. Cooper DN. Functional intronic polymorphisms: buried treasure awaiting discovery within our genes. Hum Genomics. 2010;4(5):284-8.

51. Segal LA. Controlling the immune system: diffuse feedback via a diffuse informational networks. Novartis Found Symp. 239:31-40.

52. Ghosh D, Sengupta J. Endometrial receptivity for implantation. Another look at the issue of peri-implantation oestrogen. Hum Reprod. 1995;10(1):1-7.

53. Hanamura T, Niwa T, Gohno T, Kurosumi M, Takei H, Yamaguchi $Y$, et al. Possible role of the aromatase-independent steroid metabolism pathways in hormone responsive primary breast cancers. Breast Cancer Res Treat. 2014;143(1):69-80

54. Sinreih M, Knific T, Anko M, Hevir N, Vouk K, Jerin A, et al. The significance of the sulfatase pathway for local estrogen formation in endometrial cancer. Front Pharmacol. 2017;8:368.

55. Piccinato CA, Neme RM, Torres N, Sanches LR, Derogis PBMC, Brudniewski $H F$, et al. Effects of steroid hormone on estrogen sulfotransferase and on 
steroid sulfatase expression in endometriosis tissue and stromal cells. J Steroid Biochem Mol Biol. 2016;158:117-26.

56. Bulletti C, Coccia ME, Battistoni S, Borini AJ. Endometriosis and infertility. Assist Reprod Genet. 2010;27(8):441-7.

57. Practice Committee of the American Society for Reproductive Medicine. Endometriosis and infertility: a committee opinion. Fertil Steril. 2012;98(3): 591-8.

58. Sanchez AM, Vanni VS, Bartiromo L, Papaleo E, Zilberberg E, Candiani M, et al. Is the oocyte quality affected by endometriosis? A review of the literature. J Ovarian Res. 2017;10(1):43.

59. Jones RK, Bulmer JN, Searle RF. Immunohistochemical characterization of proliferation, oestrogen receptor and progesterone receptor expression in endometriosis: comparison of eutopic and ectopic endometrium with normal cycling endometrium. Hum Reprod. 1995;10(12):3272-9.

60. Franco-Murillo Y, Miranda-Rodríguez JA, Rendón-Huerta E, Montaño LF, Cornejo GV, Gómez LP, et al. Unremitting cell proliferation in the secretory phase of eutopic endometriosis: involvement of pAkt and pGSK3 3 . Reprod Sci. 2015;22(4):502-10.

61. Pazhohan A, Amidi F, Akbari-Asbagh F, Seyedrezazadeh E, Farzadi L, Khodarahmin $M$, et al. The Wnt/ $\beta$-catenin signaling in endometriosis, the expression of total and active forms of $\beta$-catenin, total and inactive forms of glycogen synthase kinase-3 $\beta$, WNT7a and DICKKOPF-1. Eur J Obstet Gynecol Reprod Biol. 2018;220:1-5.

62. Su RW, Strug MR, Joshi NR, Jeong JW, Miele L, Lessey BA, et al. Decreased notch pathway signaling in the endometrium of women with endometriosis impairs decidualization. J Clin Endocrinol Metab. 2015;100(3): E433-42.

63. Xiong W, Zhang L, Yu L, Xie W, Man Y, Xiong Y, et al. Estradiol promotes cells invasion by activating $\beta$-catenin signaling pathway in endometriosis. Reproduction. 2015;150(6):507-16.

64. van der Horst PH, Wang Y, van der Zee M, Burger CW, Blok LJ. Interaction between sex hormones and WNT/ß-catenin signal transduction in endometrial physiology and disease. Mol Cell Endocrinol. 2012;358(2): 176-84.

65. Delvoux B, D'Hooghe T, Kyama C, Koskimies P, Hermans RJ, Dunselman GA, et al. Inhibition of type $117 \beta$-hydroxysteroid dehydrogenase impairs the synthesis of $17 \beta$-estradiol in endometriosis lesions. J Clin Endocrinol Metab. 2014;99(1):276-84.

66. Dassen H, Punyadeera C, Kamps R, Delvoux B, Van Langendonckt A, Donnez J, Husen B, Thole H, Dunselman G, Groothuis P. Estrogen metabolizing enzymes in endometrium and endometriosis. Hum Reprod. 2007;22(12): 3148-58.

67. Shao $R$, Cao S, Wang X, Feng Y, Billig $H$. The elusive and controversial roles of estrogen and progesterone receptors in human endometriosis. Am J Transl Res. 2014;6(2):104-13.

68. Han SJ, Jung SY, Wu SP, Hawkins SM, Park MJ, Kyo S, et al. Estrogen receptor $\beta$ modulates apoptosis complexes and the inflammasome to drive the pathogenesis of endometriosis. Cell. 2015;163(4):960-74.

69. Zhang Y, Zhang Y, Zhao C, Yu T, Liu Y, Shi W, et al. Reduced alternative splicing of estrogen receptor alpha in the endometrium of women with endometriosis. Oncotarget. 2017:8(66):110176-86.

70. Miller MM, McMullen PD, Andersen ME, Clewell RA, et al. Multiple receptors shape the estrogen response pathway and are critical considerations for the future of in vitro-based risk assessment efforts. Crit Rev Toxicol. 2017;47(7): 564-80.

71. Hapangama DK, Turner MA, Drury JA, Quenby S, Saretzki G, Martin-Ruiz C, et al. Endometriosis is associated with aberrant endometrial expression of telomerase and increased telomere length. Hum Reprod. 2008;23(7):1511-9.

72. Stettner M, Kaulfuss S, Burfeind P, Schweyer S, Strauss A, Ringert RH, et al. The relevance of estrogen receptor-beta expression to the antiproliferative effects observed with histone deacetylase inhibitors and phytoestrogens in prostate cancer treatment. Mol Cancer Ther. 2007;6(10):2626-33.

73. O'Malley BW, Tsai MJ. Molecular pathways of steroid receptor action. Biol Reprod. 1992;46(2):163-7

74. Bedaiwy MA, Dahoud W, Skomorovska-Prokvolit Y, Yi L, Liu JH, Falcone T, et al. Abundance and localization of progesterone receptor isoforms in endometrium in women with and without endometriosis and in peritoneal and ovarian endometriotic implants. Reprod Sci. 2015;22(9):1153-61.

75. Marquardt RM, Kim TH, Shin JH, Jeong JW. Progesterone and estrogen signaling in the endometrium: what goes wrong in endometriosis? Int J Mol Sci. 2019;20(15). https://doi.org/10.3390/ijms20153822.
76. Jacobsen BM, Horwitz KB. Progesterone receptors, their isoforms and progesterone regulated transcription. Mol Cell Endocrinol. 2012;357(1-2): 18-29.

77. Vegeto E, Shahbaz MM, Wen DX, Goldman ME, O'Malley BW, McDonnell DP. Human progesterone receptor a form is a cell- and promoter-specific repressor of human progesterone receptor B function. Mol Endocrinol. 1993; 7(10):1244-55.

78. Scarpin KM, Graham JD, Mote PA, Clarke CL. Progesterone action in human tissues: regulation by progesterone receptor (PR) isoform expression, nuclear positioning and coregulator expression. Nucl Recept Signal. 2009;7:e009.

79. Patel B, Elguero S, Thakore S, Dahoud W, Bedaiwy M, Mesiano S. Role of nuclear progesterone receptor isoforms in uterine pathophysiology. Hum Reprod Update. 2015;21(2):155-73.

80. Arnett-Mansfield RL, DeFazio A, Mote PA, Clarke CL. Subnuclear distribution of progesterone receptors $A$ and $B$ in normal and malignant endometrium. J Clin Endocrinol Metab. 2004;89(3):1429-42.

81. Lessey BA, Kim JJ. Endometrial receptivity in the eutopic endometrium of women with endometriosis: it is affected, and let me show you why. Fertil Steril. 2017;108(1):19-27.

82. Barragan F, Irwin JC, Balayan S, Erikson DW, Chen JC, Houshdaran S, et al. Human endometrial fibroblasts derived from mesenchymal progenitors inherit progesterone resistance and acquire an inflammatory phenotype in the endometrial niche in endometriosis. Biol Reprod. 2016;94(5):118. https:// doi.org/10.1095/biolreprod.115.136010.

83. Arnett-Mansfield RL, deFazio A, Wain GV, Jaworski RC, Byth K, Mote PA, et al. Relative expression of progesterone receptors $\mathrm{a}$ and $\mathrm{B}$ in endometrioid cancers of the endometrium. Cancer Res. 2001;61(11):4576-82.

84. Santoro N, Goldsmith LT, Heller D, Illsley N, McGovern P, Molina C, et al. Luteal progesterone relates to histological endometrial maturation in fertile women. J Clin Endocrinol Metab. 2000;85(11):4207-11.

85. Young SL. Oestrogen and progesterone action on endometrium: a translational approach to understanding endometrial receptivity. Reprod BioMed Online. 2013;27(5):497-505

86. Sengupta J, Ghosh D. Multi-level and multi-scale integrative approach to the understanding of human blastocyst implantation. Prog Biophys Mol Biol. 2014:114(1):49-60.

87. Macer ML, Taylor HS. Endometriosis and infertility: a review of the pathogenesis and treatment of endometriosis-associated infertility. Obstet Gynecol Clin N Am. 2012;39(4):535-49.

88. Tapia-Pizarro A, Figueroa P, Brito J, Marín JC, Munroe DJ, Croxatto HB. Endometrial gene expression reveals compromised progesterone signaling in women refractory to embryo implantation. Reprod Biol Endocrinol. 2014; 12:92.

89. Mathyk B, Adams N, Young SL. Endometrial receptivity: lessons from systems biology and candidate gene studies of endometriosis. Minerva Ginecol. 2017;69(1):41-56.

90. Jansen R, Greenbaum D, Gerstein M. Relating whole-genome expression data with protein-protein interactions. Genome Res. 2002;12(1):37-46.

91. Liu Y, Beyer A, Aebersold R. On the dependency of cellular protein levels on mRNA abundance. Cell. 2016;165(3):535-50.

92. Golub TR, Slonim DK, Tamayo P, Huard C, Gaasenbeek M, Mesirov JP, et al. Molecular classification of cancer: class discovery and class prediction by gene expression monitoring. Science. 1999;286(5439):531-7.

93. Macgregor PF, Squire JA. Application of microarrays to the analysis of gene expression in cancer. Clin Chem. 2002;48(8):1170-7.

94. Vogel C, Marcotte EM. Insights into the regulation of protein abundance from proteomic and transcriptomic analyses. Nat Rev Genet. 2012;13(4): 227-32.

95. Greenbaum D, Colangelo C, Williams K, Gerstein M. Comparing protein abundance and mRNA expression levels on a genomic scale. Genome Biol. 2003;4(9):117.

96. Yates EF. Self-organizing systems. In: Boyd CAR, Noble D, editors. Logic of Life. Ed. New York: Oxford University Press; 1993. p. 189-218.

97. Clancy KB. Reproductive ecology and the endometrium: physiology, variation, and new directions. Am J Phys Anthropol. 2009;140(Suppl 49): $137-54$

\section{Publisher's Note}

Springer Nature remains neutral with regard to jurisdictional claims in published maps and institutional affiliations. 